\title{
Visualizing Belief and Piety in Iranian Shi'ism
}

\author{
Ingvild Flaskerud
}

New York: Continuum, 2010. hbk. 306 pages.

In her book, Ingvild Flaskerud once and for all dispels the idea that Islam lacks and opposes all forms of visual art. Hers is a pioneering work, which guides her readers through Twelver Shi'i visual culture in Iran. She frames her discussion by drawing on semiotic theory, particularly Charles Sanders Peirce and Roland Barthes, in order to show both the interpretive possibilities inherent in visual piety and the ways in which meaning is fixed. Flaskerud is uniquely positioned for writing about visual piety, as she has already produced an artistic visual film ("Standard Bearers of Hussein: Women Commemorating Karbala," 2003) on Shi'i women's practices in Iran. Visualizing Belief and Piety in Iranian Shi 'ism is a Geertzian "thick description" (Geertz, The Interpretation of Cultures) composed of three parts, each of which is followed by black-and-white pictures analyzed in that part. The first two parts address two iconographic themes respectively. The third discusses the usage of pious art in votive practices and ritual spaces. 
In the first part of her book Flaskerud examines the symbolism and pictorial representations of the first Shi' $i$ Imam, 'Ali ibn Abu Talib. She explains that in the nineteenth century, images of "Ali had circulated in the form of lithographic booklets. Drawing on these popular representations, as well as European and Iranian style imperial effigies, Nasir al-Din Shah (d. 1896 AC) introduced portraits of 'Ali, which he wore on his chest from the 1850s onwards in order to represent himself as the protector of the faithful. Next, in this same first part, Flaskerud discusses Shi'i views of 'Ali's historical and spiritual roles, how these are translated into a system of symbols, and how those symbols are perceived by Iranian Shi'is.

In part two, Flaskerud looks at artistic portrayals of the Battle of Karbala $(680$ AC). She weaves in the historical background of depicted events as she explicates how visual representations relate and compare to Karbala mourning poetry, ritual mourning gatherings, and theatrical performances of the Karbala narrative. Unlike images of saints who, like 'Ali, are often represented as portraits, scenes from the Battle of Karbala represent saints symbolically, for instance, by depicting rider-less horses or even shrines wherein they are buried.

In the third part, Flaskerud situates religious images by describing votive practices or religious vows (nazr), ritual mourning gatherings, and saints' birthday celebrations (mowludi). Unlike in Christian votive practices, Shi'i votive images seldom depict the votive process itself. Instead, the images typically depict the saint, with whom a devotee has entered into a vow. Devotees may purchase and donate an image - such as a wall hanging depicting the Battle of Karbala as a result of or in order to ensure the successful fulfillment of a vow.

While examining ritual spaces, she finds that there are few differences between male and female spaces with regard to their visual pious practices, except that men's ritual spaces often have better resources and are thus able to afford more expensive wall hangings. In discussing these spaces, Flaskerud lastly mentions two exceptional posters she found in different ritual halls: the first was a picture of Mary (Mariam), and the second was a picture of two deer. She argues that images that might be considered kitsch in the Euro-American art scene are accepted as appropriate for Iranian Shi'is as long as they can be reread into a Shi' $\mathrm{i}$ worldview. Lastly, Flaskerud also examines the Qur'anic prohibition on imagery and idolatry, which she enriches by discussing the attitudes of contemporary Shi'i scholars in Iran who allow religious art as long as it serves religion. 
What makes this book interesting, aside from its rarely discussed subject matter, are the short vignettes about 'Ali, Hussein, and the story of Karbala. They add spice to the otherwise lengthy descriptions of pious artistic representations. Though Flaskerud's work represents a valuable contribution to the study of Islamic visual piety, it could have been improved in a number of ways. Occasionally, it reads more like a dissertation than a book for a generally educated and interested audience. There are inconsistencies in the index. For example, scholars are sometimes listed by their last names and sometimes by their first names. Moreover, scholars are quoted, but seldom introduced. The detailed descriptions of images and their discussions could have been stated more concisely. While the overarching argument is clear, it could have been elaborated more fully considering the length of the book. Theoretically, it would have become more interesting had Flaskerud engaged some of the other theoretically-oriented works on art and material culture in the Islamic world (e.g., Starrett, "The Political Economy of Religious Commodities in Cairo" ). A consideration of Walter Benjamin's thoughts on "Art in the Age of Mechanical Reproduction" would have added another layer of depth. Finally, from an ethnographic point of view, readers rarely get a deeper sense of who is saying what. Instead, individual interlocutors are noted by their age or socio-economic status. And while Flaskerud's overarching argument has to do with potential variety in individual interpretation, readers seldom meet individual Shi'is who engage in interpretation.

Notwithstanding these comments, as a pioneering work, the book is useful especially for upper-level undergraduate courses on Islam and material or visual culture. Moreover, it would be especially interesting to Sunni Muslims, as Flaskerud provides a sensitive and sympathetic account of Shi'i visual piety. Though the implied opposition of Sunni prohibition and Shi' $i$ permissibility of images is problematic, she nonetheless successfully shows how Shi'is navigate religious prohibitions regarding visual arts.

\section{Bibliography}

Benjamin, Walter. "Art in the Age of Mechanical Reproduction." In Illuminations, edited by Hannah Arendt and translated by Harry Zohn, 217-52. New York: Schocken Books, 1969.

Geertz, Clifford. The Interpretation of Cultures. New York: Basic Books, 1973. 
Starrett, Gregory. "The Political Economy of Religious Commodities in Cairo." American Anthropologist, 97 no. 1 (1995): 51-68.

Edith Szanto Doctoral Candidate, Centre for the Study of Religion, University of Toronto Lecturer in History, American University of Iraq - Sulaimani 